\title{
The Potential \\ to Use Smartphone-based GNSS Receivers for Surveying
}

\begin{abstract}
The aim of the present study was to investigate the possibility of using smartphone-grade GNSS receivers for surveying purposes and to examine their accuracy in terms of positioning. The paper presents an analysis of the results of test measurements made using two smartphones: a Huawei P8 lite, powered by Android 6.0 and an iPhone 6s, operating on IOS 10.1.1. Both devices were equipped with GPS and GLONASS modules and had the supporting system, A-GPS. Measurements were made on two test parcels of different shapes and sizes. The test procedure encompassed three measurement series (I-III), each of which consisted of five determinations. The determinations were done at 5-min time intervals and each new measuring session began after $90 \mathrm{~min}$ from the previous one. Measurements with the Huawei P8 lite were taken using the Locus Map app, and measurements with the iPhone $6 \mathrm{~s}$ were performed with the use of Map-o-meter. The study consisted of determining the positioning accuracy of the test smartphones by comparing the results with reference coordinates obtained from RTN measurements using the Topcon HiPer V receiver with Magnet Tools software. Determinations of the reference coordinates were done with the help of the TPI NetPro network real-time service corrections.
\end{abstract}

Keywords: AGPS, GNSS, smartphone, measurements, RTN

Received: 20 May 2017; accepted: 29 June 2019

(C) 2020 Author. This is an open access publication, which can be used, distributed and reproduced in any medium according to the Creative Commons CC-BY 4.0 License.

1 University of Life Sciences in Lublin, Department of Environmental Engineering and Geodesy, Lublin, Poland, email: justyna.gabryszuk@up.lublin.pl

ORCID ID: https://orcid.org/0000-0002-6334-6469 


\section{Introduction}

The rapid technological development and miniaturization of GNSS receivers allowed their use in mobile phones. The first device of this type was the Benefon ESC! phone, released in 1999, equipped with a GPS positioning system operating on two GSM frequencies of 900 and $1800 \mathrm{MHz}$ [1]. It had a fairly broad array of features such as displaying the user's position on a map, calculating the position, elevation above sea level and average speed, and setting the current position and destination waypoints. Following the announcement in 2011 of full operational capability of the GLONASS system [2], it became standard practice to use two navigation systems in smartphones. The first smartphone of this type was ZTE MTS 945 [3]. Today, smartphones use solutions supporting the operation of satellite navigation systems such as Assisted GPS (A-GPS), Enhanced GPS (E-GPS) [1], Mobile RTK (mRTK) [4,5], and Beidou, the Chinese satellite navigation system.

A-GPS augments GPS positioning in poor satellite signal conditions, e.g. in urban canyons and closed facilities [6]. Auxiliary information needed to determine the coordinates is supplied directly by the cellular network via GPRS, a packet-oriented mobile data service [1]. A-GPS shortens the time needed to download ephemeris data by supplying them directly from the mobile station, instead of the slower satellite link. Mobile RTK (mRTK) solution enable high-accuracy double difference carrier phase positioning using a smartphone [5]. It utilizes single-band assisted-GPS receivers, cellular link and inertial sensors [4]. Recently, it has been proven that positioning using CDGNSS (carrier-phase differential GNSS) with centimeter accuracy is possible, using low-quality, low-cost antennas mounted in smartphones [7]. However, miniaturized GPS chipsets still cannot compete with the sturdy high-accuracy antenna systems of precision GPS receivers [8].

Current technological development makes it relatively easy to create Web services for everyday use [9], which is why there are more and more applications available online that use GNSS services to perform measurements. The most frequently downloaded free applications include GPS Essentials, Locus Free Maps and GPS Measure Field Area for Android and iGeoTrans Lite, Map-o-meter, and Area - Calculate my Area for iOS.

The aim of the present study was to test the accuracy of determination of horizontal coordinates using smartphone-based GNSS receivers and to analyze the possibility of their use in surveying. The study also compared the results of determinations made using smartphones with those made using the RTN Topcon Hiper V set with the FC-2600 controller.

\section{Method}

The study examined the positioning accuracy of two popular one-frequency GNSS smartphones: the Huawei P8 lite powered by the Android 6.0 operating 
system and an iPhone 6s operating on IOS version 10.1.1. Both devices had GPS and GLONASS modules and the supporting system, A-GPS.

The tests were performed on November $2^{\text {nd }}, 2016$ between 11.00 and 16.00 hours on two test parcels differing in shape and surface area. The parcels were established in the city of Lublin, in Józef Sowiński Street, and were marked with wooden stakes (Fig. 1). They were located in optimum field conditions with a very good view of the sky. The PDOP (position dilution of precision) coefficient during measurement ranged from 1.01 and 1.36 [10].
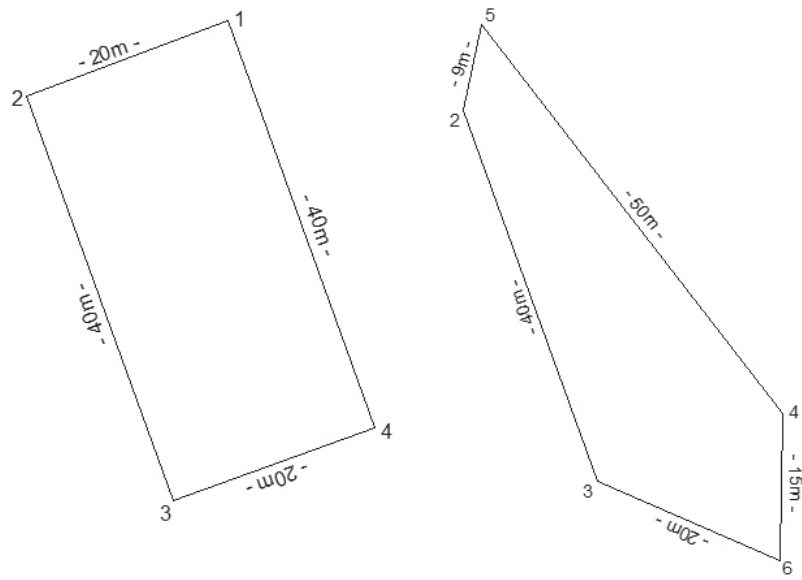

Fig. 1. Test parcel 1 and test parcel 2

Source: [11]

Since there is no ISO standard for accuracy testing of GNSS measurements performed with smartphones, we proposed a new procedure based partly on ISO 17123-8 GNSS Field Measurement Systems in Real-Time Kinematic (RTK) as described by [12]. This procedure encompassed three measurement series (I-III), each of which consisted of five determinations (A, B, C, D, E). The determinations were done at 5-min time intervals and each new measuring session began after $90 \mathrm{~min}$ from the previous one. This was done to minimize the impact of changes in the configuration of satellites, deviation of their orbits, as well as ionospheric, tropospheric and environmental conditions of the receiver. The results of the determinations were compared with a Real Time Network (RTN) measurement performed using the Topcon HiPer V receiver with Magnet Field software using TPI NETpro VRS corrections. This receiver can be used to determine the horizontal position to an accuracy of $1 \mathrm{~cm}$ [13].

Because the test smartphones had different operating systems, the tests were done using different measurement applications. Determinations with the Huawei P8 lite were done using Locus Map, and measurements with the iPhone 6s were performed with the use of Map-o-meter. Both applications allow the setting of individual waypoints and route-tracking. 


\section{Results and Discussion}

To visualize the results, the observation data obtained in KML format were imported to the QGIS geographic information system application. The results of determinations of the vertices of the test parcels are presented in Figures 2 and 3. One notices immediately that the coordinates measured using the iPhone $6 \mathrm{~s}$ are more precise and are more closely clustered around the results of the RTN measurement (marked in aquamarine) than those measured with Huawei P8 lite.

As a next step, standard deviations of the results were calculated using Microsoft Excel. Figure 4 shows a comparison of standard deviations of the horizontal coordinates of the vertices of test parcels 1 and 2. An analysis of the data in Figure 4 shows that the largest standard deviations were obtained when positioning was done with the Huawei P8 lite. They fell within the range of 1.32 to $4.15 \mathrm{~m}$ for the $X$ coordinate and 1.63 to $2.87 \mathrm{~m}$ for the $\mathrm{Y}$ coordinate. The standard deviations for the iPhone $6 \mathrm{~s}$ were in the range of 0.53 to $2.42 \mathrm{~m}$ for $\mathrm{X}$ and 0.92 to $1.88 \mathrm{~m}$ for $\mathrm{Y}$.

a)

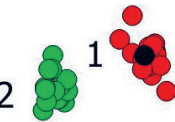

b)
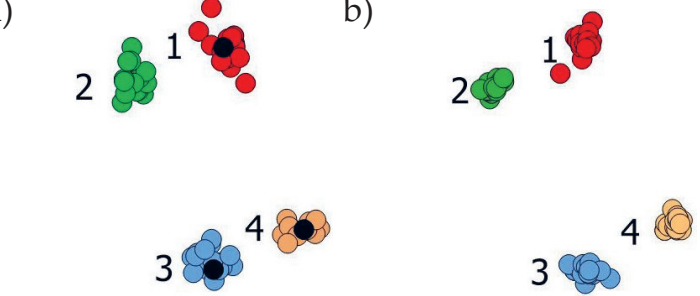

$0102030 \mathrm{~m}$
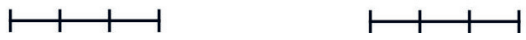

Fig. 2. Determinations of parcel 1 vertices in all measurement series:

a) Huawei P8 lite; b) iPhone $6 \mathrm{~s}$

a)
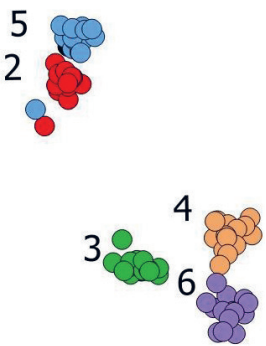

b)
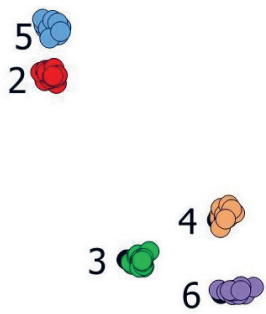

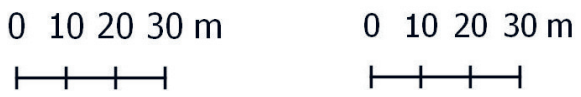

Fig. 3. Determinations of parcel 2 vertices in all measurement series:

a) Huawei P8 lite; b) iPhone $6 \mathrm{~s}$ 
a) $[\mathrm{m}]$

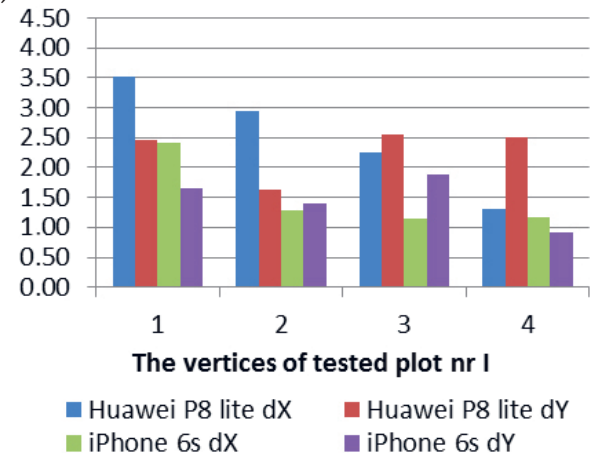

b) $[\mathrm{m}]$

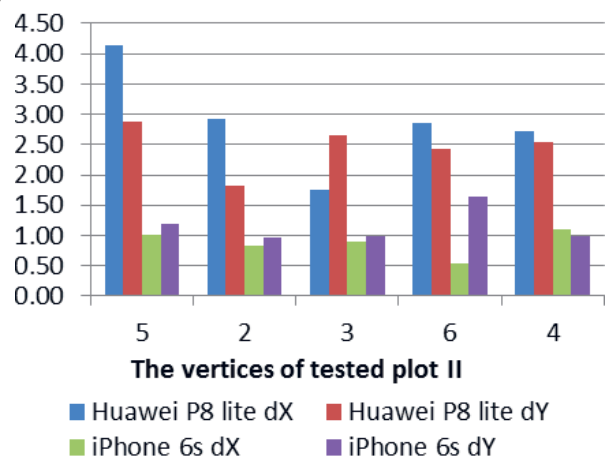

Fig. 4. Standard deviations of coordinates of horizontal boundary points of the test parcel: a) plot I; b) plot II

An analysis of Figure 5, presenting the standard deviations of a single point position determination, demonstrates that the measurement taken with iPhone $6 \mathrm{~s}$ exhibited a much smaller error than that performed using Huawei P8 lite. The mean error was $1.75 \mathrm{~m}$ for the horizontal coordinates. To compare, the mean error for Huawei P8 lite was more than twice as large at $3.67 \mathrm{~m}$.

a) $[\mathrm{m}]$

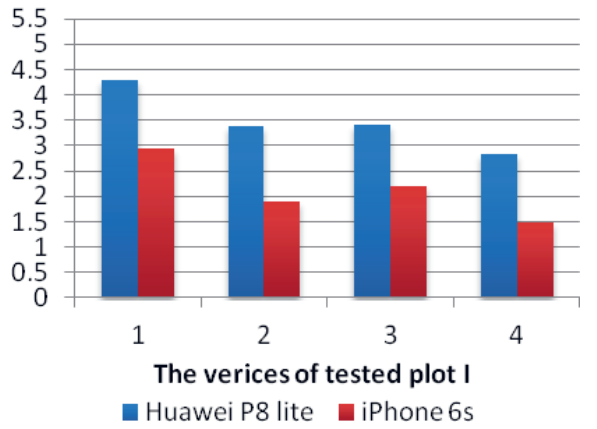

b) $[\mathrm{m}]$

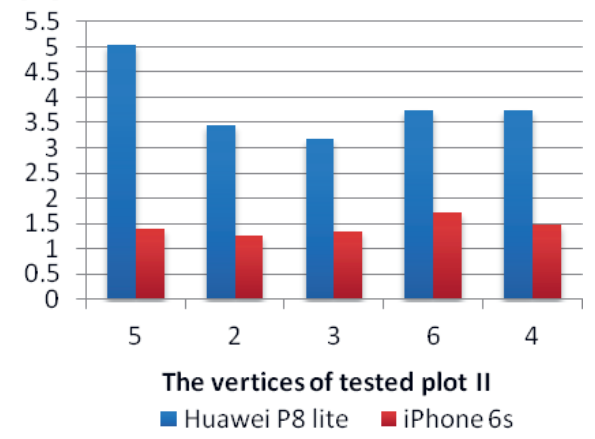

Fig. 5. Standard deviations of a single point position determination: a) plot I; b) plot II

On the basis of an analysis of Tables 1 and 2, depicting differences between the RTN measurement made with the HiPer V receiver and the measurements taken with the smartphones, it can be observed that the average values of the positioning done with the Huawei P8 lite were more similar to the RTN measurement. The mean error of horizontal position determination $\mathrm{mP}$ was $1.33 \mathrm{~m}$ for parcel 1 vertices, $1.82 \mathrm{~m}$ for the vertices of parcel 2 , and $1.60 \mathrm{~m}$ for all points measured, with the respective values for the iPhone $6 \mathrm{~s}$ being $2.24 \mathrm{~m}, 1.80 \mathrm{~m}$, and $2.00 \mathrm{~m}$. However, based on the confidence interval analysis, it should be noted that measurement done with an iPhone $6 \mathrm{~s}$ smartphone allows more precise results. The average confidence interval for the mean for iPhone $6 \mathrm{~s}$ 
noticed in parcel 1 was between -1.65 and $0.02 \mathrm{~m}$ for $\mathrm{dX}$ and -2.01 and $-0.40 \mathrm{~m}$ for $\mathrm{dY}$. The same value for the Huawei P8 lite was between -1.94 and $0.99 \mathrm{~m}$ for $\mathrm{dX}$ and -1.44 and $1.38 \mathrm{~m}$ for $\mathrm{dY}$. In the case of parcel 2, the average confidence interval for the iPhone $6 \mathrm{~s}$ was from $-1,23$ to $-0.25 \mathrm{~m}$ for $\mathrm{dX}$ and -2.21 to $-0.94 \mathrm{~m}$ for $\mathrm{dY}$ and for the Huawei P8 lite between -1.83 and $1.36 \mathrm{~m}$ for $\mathrm{dX}$ and -1.31 and $1.42 \mathrm{~m}$ for $\mathrm{dY}$.

Table 1. Differences in the coordinates of parcel 1 vertices between the RTN measurement and the selected smartphones measurements in meters

\begin{tabular}{|c|c|c|c|c|c|c|c|}
\hline \multirow{2}{*}{\multicolumn{2}{|c|}{$\begin{array}{l}\text { Number } \\
\text { of point and } \\
\text { coordinate }\end{array}$}} & \multicolumn{3}{|c|}{ Huawei P8 lite } & \multicolumn{3}{|c|}{ iPhone $6 \mathrm{~s}$} \\
\hline & & \multirow{2}{*}{$\begin{array}{c}\text { average } \\
0.01\end{array}$} & \multirow{2}{*}{$\begin{array}{c}-95 \% \\
\begin{array}{c}-95 \\
\text { confidence } \\
\text { interval for } \\
\text { the mean }\end{array} \\
-1.94\end{array}$} & \multirow{2}{*}{$\begin{array}{c}\begin{array}{c}95 \% \\
\text { confidence } \\
\text { interval for } \\
\text { the mean }\end{array} \\
1.97\end{array}$} & \multirow{2}{*}{$\begin{array}{c}\text { average } \\
-1.06\end{array}$} & \multirow{2}{*}{$\begin{array}{c}-95 \% \\
\text { confidence } \\
\text { interval for } \\
\text { the mean }\end{array}$} & \multirow{2}{*}{$\begin{array}{c}95 \% \\
\begin{array}{c}95 \\
\text { confidence } \\
\text { interval for } \\
\text { the mean }\end{array} \\
0.28\end{array}$} \\
\hline 1 & $\mathrm{dX}$ & & & & & & \\
\hline 1 & $d Y$ & -0.62 & -1.98 & 0.73 & 0.27 & -0.64 & 1.18 \\
\hline \multirow{2}{*}{2} & $\mathrm{dX}$ & -1.74 & -3.37 & -0.1 & -0.62 & -1.34 & 0.09 \\
\hline & $d Y$ & 0.08 & -0.96 & 1.11 & -0.03 & -0.8 & 0.74 \\
\hline \multirow{2}{*}{3} & $\mathrm{dX}$ & -0.27 & -1.8 & 1.26 & 0.11 & -0.52 & 0.74 \\
\hline & $d Y$ & 0.12 & -1.74 & 1.97 & -2.77 & -3.81 & -1.73 \\
\hline \multirow{2}{*}{4} & $\mathrm{dX}$ & 0.08 & -0.65 & 0.81 & -1.67 & -2.32 & -1.02 \\
\hline & $\mathrm{dY}$ & 0.33 & -1.06 & 1.72 & -2.28 & -2.79 & -1.77 \\
\hline \multirow{2}{*}{ Average } & $\mathrm{dX}$ & -0.48 & -1.94 & 0.99 & -0.81 & -1.65 & 0.02 \\
\hline & $d Y$ & -0.02 & -1.44 & 1.38 & -1.20 & -2.01 & -0.40 \\
\hline
\end{tabular}

Source: own elaboration on the basis of [11]

Table 2. Differences in the coordinates of parcel 2 vertices between the RTN measurement and the selected smartphones measurements in meters

\begin{tabular}{|c|c|c|c|c|c|c|c|}
\hline \multirow{2}{*}{\multicolumn{2}{|c|}{$\begin{array}{l}\text { Number } \\
\text { of point and } \\
\text { coordinate }\end{array}$}} & \multicolumn{3}{|c|}{ Huawei P8 lite } & \multicolumn{3}{|c|}{ iPhone $6 \mathrm{~s}$} \\
\hline & & \multirow{2}{*}{$\begin{array}{c}\text { average } \\
-0.81\end{array}$} & \multirow{2}{*}{$\begin{array}{c}-95 \% \\
\text { confidence } \\
\text { interval for } \\
\text { the mean }\end{array}$} & \multirow{2}{*}{$\begin{array}{c}\begin{array}{c}95 \% \\
\text { confidence } \\
\text { interval for } \\
\text { the mean }\end{array} \\
1.49\end{array}$} & \multirow{2}{*}{$\begin{array}{c}\text { average } \\
-1.56\end{array}$} & \multirow{2}{*}{$\begin{array}{c}-95 \% \\
\text { confidence } \\
\text { interval for } \\
\text { the mean }\end{array}$} & \multirow{2}{*}{$\begin{array}{c}95 \% \\
\text { confidence } \\
\text { interval for } \\
\text { the mean }\end{array}$} \\
\hline & $\mathrm{dX}$ & & & & & & \\
\hline 5 & $\mathrm{dY}$ & -1.49 & -3.08 & 0.10 & 0.21 & -0.45 & 0.87 \\
\hline \multirow{2}{*}{2} & $\mathrm{dX}$ & -1.32 & -2.94 & 0.29 & -0.76 & -1.22 & -0.29 \\
\hline & $\mathrm{dY}$ & -0.58 & -1.59 & 0.42 & -0.81 & -1.34 & -0.29 \\
\hline \multirow{2}{*}{3} & $\mathrm{dX}$ & -1.19 & -2.16 & -0.22 & 0.15 & -0.35 & 0.66 \\
\hline & $\mathrm{dY}$ & 0.78 & -0.69 & 2.25 & -2.62 & -3.16 & -2.07 \\
\hline \multirow{2}{*}{6} & $\mathrm{dX}$ & 1.25 & -0.33 & 2.84 & -0.55 & -0.85 & -0.26 \\
\hline & $\mathrm{dY}$ & 1.42 & 0.08 & 2.76 & -3.06 & -3.97 & -2.15 \\
\hline \multirow{2}{*}{4} & $\mathrm{dX}$ & 0.88 & -0.63 & 2.39 & -0.99 & -1.60 & -0.38 \\
\hline & $\mathrm{dY}$ & 0.16 & -1.26 & 1.57 & -1.6 & -2.15 & -1.06 \\
\hline \multirow{2}{*}{ Average } & $\mathrm{dX}$ & -0.24 & -1.83 & 1.36 & -0.74 & -1.23 & -0.25 \\
\hline & $d Y$ & 0.06 & -1.31 & 1.42 & -1.58 & -2.21 & -0.94 \\
\hline
\end{tabular}

Source: own elaboration on the basis of [11] 


\section{Conclusions}

Comparing the results of the present study with the results of [1], it can be stated that the differences between measurements taken with an RTN precision receiver and a smartphone have decreased fivefold over the last 6 years. The current rapid development of mobile phones and GNSS chipsets, which are their inseparable components, shows that the measurement accuracy of smartphones may greatly improve in a short time.

Studies have shown that smartphones can be used for quick and easy measurement of horizontal coordinates but are not very precise instruments. The mean standard deviations of determinations of horizontal coordinates were in the range from 1.27 to $2.93 \mathrm{~m}$ for the iPhone $6 \mathrm{~s}$ and from 2.84 to $5.04 \mathrm{~m}$ for the Huawei P8. The accuracy of point determinations was $1.60 \mathrm{~m}$ for the Huawei P8 lite and $2.00 \mathrm{~m}$ for the iPhone $6 \mathrm{~s}$. The average confidence interval for the mean for the iPhone $6 \mathrm{~s}$ was between -1.44 and $-0.12 \mathrm{~m}$ for $\mathrm{dX}$ and -2.11 and $-0.67 \mathrm{~m}$ for $\mathrm{dY}$ and for the Huawei P8 lite between -1.89 and $1.17 \mathrm{~m}$ for $\mathrm{dX}$ and -1.37 and $1.40 \mathrm{~m}$ for $\mathrm{dY}$.

The accuracy of the measurements taken with the smartphones was within the range of accuracies provided by the ASG-EUPOS NAWGIS service (1-3 m) which assists satellite navigation and the field control of topographic maps and GIS systems [14]. They can also be used for mapping-survey measurements performed to create or update a database for group II and III field details (3 m - group II, $5.0 \mathrm{~m}$ group III, §29.2. [15]). However, the much worse accuracy of the measurements indicates that the variation of the obtained coordinates may be large. Additional studies of the accuracy of smartphone measurements in less favorable conditions, for example, in the vicinity of densely built-up areas, should be carried out to establish whether such an application is practicable.

\section{References}

[1] Ciećko A., Kaźmierczak R., Grunwald G., Borowski B.: Nawigacja satelitarna GPS z wykorzystaniem telefonu komórkowego. Logistyka, nr 6, 2011, pp. 513-523.

[2] Gabryszuk J.: Wpływ kata odcięcia horyzontu na wyznaczanie pozycji w trybie RTN GNSS z siecia TPI NETpro oraz VRSNet. Infrastruktura i Ekologia Terenów Wiejskich, nr II/1/2016, pp. 299-309.

[3] Ciećko A., Grunwald G., Łątka K.: Analiza dokładności pozycjonowania pojazdu w ruchu miejskim za pomoca smartfonów wyposażonych w chipset GPS oraz GPS/ GLONASS. Logistyka, nr 3, 2015, pp. 737-743.

[4] Alanen K., Wirola L., Kappi J., Syrjarinne J.: Inertial sensor enhanced mobile rtk solution using low-cost assisted GPS receivers and internet-enabled cellular phones. [in:] 2006 IEEE/ION Position, Location and Navigation Symposium, IEEE, 2006, pp. 920-926. 
[5] Wirola L., Alanen K., Kappi J., Syrjarinne J.: Bringing RTK to Cellular Terminals Using a Lowcost Single-Frequency AGPS Receiver and Inertial Sensors. [in:] 2006 IEEE/ION Position, Location and Navigation Symposium, IEEE, 2006, pp. 645-652.

[6] Borkowski J., Niemelä J., Lempiäinen J.: Cellular location techniques supporting AGPS positioning. [in:] Vehicular Technology Conference, 2005. VTC-2005-Fall. 2005 IEEE 62 ${ }^{\text {nd }}$, Volume 1, IEEE, 2005, pp. 429-433.

[7] Pesyna K.M., Jr, Heath R.W., Jr, Humphreys T.E.: Centimeter positioning with a smartphone-quality GNSS antenna. [in:] Proceedings of the ION GNSS+ Meeting, 2014. https://repositories.lib.utexas.edu/bitstream/handle/2152/63211/ ion2014Pesyna.pdf?sequence=2\&isAllowed=y [access: 19.04.2017].

[8] Zandbergen P.A., Barbeau S.J.: Positional accuracy of assisted GPS data from high-sensitivity GPS-enabled mobile phones. Journal of Navigation, vol. 64, issue 3, 2011, pp. 381-399.

[9] Kempa K., Nieszporek K., Wawszczak A.: Smartfon jako źródło informacji turystycznych w nowoczesnym mieście. Zeszyty Naukowe Uniwersytetu Szczecińskiego. Studia Informatica, nr 29, 2012, pp. 31-41.

[10] Trimble GNSS Planning Online. http://www.gnssplanningonline.com/\#/ charts [access: 19.04.2017].

[11] Szabłowska E., Szczygielska A.: Wykorzystanie pomiarów GNSS przy użyciu smartfonów do celów geodezyjnych. Wydział Inżynierii Produkcji, Katedra Inżynierii Kształtowania Środowiska i Geodezji, Uniwersytet Przyrodniczy w Lublinie, 2017 [engineer diploma thesis].

[12] Pawłowski W.: Uwarunkowania prawne $i$ techniczne procedur geodezyjnych w budownictwie. Monografie Politechniki Łódzkiej, Wydawnictwo Politechniki Łódzkiej, Łódź 2013.

[13] Hiper V. Instrukcja obstugi. Topcon, TPI Sp. z o.o.

[14] Graszka W., Oruba A., Ryczywolski M., Wajda S.: Poradnik użytkownika ASG-EUPOS. Główny Urząd Geodezji i Kartografii, Warszawa 2013. http:// www.asgeupos.pl/webpg/graph/standards/Poradnik\%20ASG-EUPOS\%20 2014.pdf [access: 19.04.2017].

[15] Rozporzadzenie Ministra Spraw Wewnętrznych i Administracji z dnia 9 listopada 2011 r. w sprawie standardów technicznych wykonywania geodezyjnych pomiarów sytuacyjnych i wysokościowych oraz opracowywania i przekazywania wyników tych pomiarów do państwowego zasobu geodezyjnego i kartograficznego. Dz.U. 2011 nr 263, poz. 1572. 


\section{Analiza możliwości wykorzystania odbiorników GNSS w smartfonach do celów geodezyjnych}

Streszczenie: Celem pracy jest odpowiedź na pytanie o możliwość wykorzystania odbiorników GNSS zainstalowanych w telefonach komórkowych typu smartfon do celów geodezyjnych oraz zbadanie dokładności wyznaczania pozycji. W pracy przeanalizowano wyniki pomiarów testowych wykonanych za pomocą dwóch smartfonów: Huawei P8 lite z systemem Android 6.0 oraz Iphone $6 \mathrm{~s}$ z systemem IOS 10.1.1. Oba urządzenia wyposażone są w odbiornik GPS i GLONASS oraz system wspomagający A-GPS. Pomiary wykonano na dwóch działkach testowych o różnym kształcie i powierzchni. Procedura testowa obejmowała trzy serie pomiarowe, przy czym każda z nich składała się z pięciu wyznaczeń. Między kolejnymi wyznaczeniami zachowano odstęp czasowy 5 minut, a każda sesja pomiarowa rozpoczynała się po upływie 90 minut. W czasie pomiaru smartfonem Huawei P8 lite skorzystano z aplikacji Locus Map, zaś podczas pomiaru smartfonem Iphone 6s z aplikacji Map-o-meter. Działki testowe znajdowały się na terenie Lublin przy ulicy Józefa Sowińskiego. Badania polegały na określeniu dokładności wyznaczenia pozycji przez wybrane smartfony na podstawie porównania otrzymanych wyników ze współrzędnymi referencyjnymi uzyskanymi z pomiaru metodą powierzchniową RTN odbiornikiem Topcon Hiper V z oprogramowaniem Magnet Tools. W czasie wyznaczania współrzędnych referencyjnych skorzystano z poprawek serwisu czasu rzeczywistego sieci TPI NETpro.

Słowa

kluczowe: AGPS, GNSS, smartfon, pomiary, RTN 